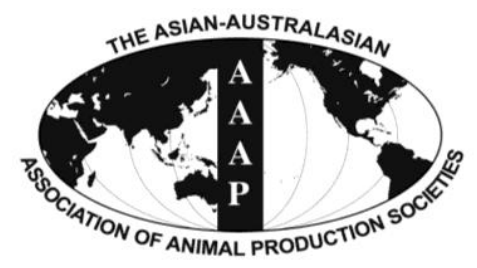

Asian-Aust. J. Anim. Sci.

Vol. 26, No. 4 : 488-500 April 2013

http://dx.doi.org/10.5713/ajas.2012.12519

www.ajas.info

pISSN 1011-2367 elSSN 1976-5517

\title{
Ovarian Follicular Dynamics, Ovarian Follicular Growth, Oocyte Yield, In vitro Embryo Production and Repeated Oocyte Pick Up in Thai Native Heifers Undergoing Superstimulation
}

\author{
J. Chasombat, T. Nagai ${ }^{1,2}$, R. Parnpai ${ }^{3}$ and T. Vongpralub* \\ Department of Animal Science, Faculty of Agriculture, Khon Kaen University, Khon Kaen 40002, Thailand
}

\begin{abstract}
The objective of this study was to compare the effectiveness of the protocols for superstimulation of follicular growth in Thai native heifers. Heifers $(n=20)$ were randomly divided into four groups of five heifers/group. Heifers were given a single dose by i.m. administration of $100 \mathrm{mg}$ Follicle Stimulating Hormone dissolved in polyvinylpyrrolidone (FSHp) at $24 \mathrm{~h}$. Ovum pick up (OPU) occurred at $72 \mathrm{~h}\left(\mathrm{~F}_{24} \mathrm{O}_{72}\right.$ protocol; Group 1) or $96 \mathrm{~h}\left(\mathrm{~F}_{24} \mathrm{O}_{96}\right.$ protocol; Group 2), and at $36 \mathrm{~h}$ and OPU at $72 \mathrm{~h}\left(\mathrm{~F}_{36} \mathrm{O}_{72}\right.$ protocol; Group 3$)$ or $96 \mathrm{~h}\left(\mathrm{~F}_{36} \mathrm{O}_{96}\right.$ protocol; Group 4) after follicular ablation. The dynamics of ovarian follicular growth were monitored by twice-daily ultrasonographic examinations. Blood sample collections were performed every $12 \mathrm{~h}$ after initiation of treatment for assessment of FSH, E2 and P4 profiles. All heifers were subjected to eight repeated sequential sessions of OPU. The follicular deviation commenced $24 \pm 5.32 \mathrm{~h}$ after follicular ablation in all groups. The circulatory FSH surged quickly from 24 to $36 \mathrm{~h}$ ( $>0.8 \mathrm{ng} / \mathrm{ml}) \mathrm{after}$ follicular ablation and circulatory estrogen levels steadily increased from $36 \mathrm{~h}$ until OPU in all groups. At the end of the OPU sessions, the mean number of aspirated follicles/heifer/session in $\mathrm{F}_{36} \mathrm{O}_{72}$ protocol (Group 3) and $\mathrm{F}_{36} \mathrm{O}_{96}$ protocol (Group 4) were higher than in the two other groups ( $\mathrm{p}<0.05)$. The number of cumulus-oocyte complexes (COCs), cleaved and day 8 blastocysts rates in the $\mathrm{F}_{36} \mathrm{O}_{72}$ protocol $(\mathrm{Group}$ 3 ) were higher than in the other groups ( $\mathrm{p}<0.05$ ). It can be concluded that a single dose i.m. administration of $100 \mathrm{mg}$ FSHp at $36 \mathrm{~h}$ and OPU at $72 \mathrm{~h}$ after follicular ablation $\left(\mathrm{F}_{36} \mathrm{O}_{72}\right.$ protocol; Group 3) was the most effective protocol for superstimulation of follicular growth for repeated OPU and subsequent in vitro embryo production in Thai native heifers. (Key Words: FSH, Follicle, OPU, COCs, IVP, Cattle)
\end{abstract}

\section{INTRODUCTION}

Currently, beef cattle production worldwide is affected from global warming and climate change (Koneswaran and Nierenberg, 2008). It has had an effect on the animal production and thus food safety and food security (KabuboMariara, 2009). In view of these concerns, the genetics of native cattle is becoming increasingly important to cattle breeding programs once again, because of the need for cattle to adapt to the local environment in tropical or subtropical environments (Tomley and Shirley, 2009).

\footnotetext{
* Corresponding Author: T. Vongpralub. Tel: +66-4320-2362, Fax: +66-4320-2362, E-mail: vthevi@kku.ac.th

${ }^{1}$ NARO Institute of Livestock and Grassland Science, Ibaraki 305-090, Japan.

${ }^{2}$ WCU Biomodulation Major, Department of Agricultural Biotechnology, College of Agriculture and Life Sciences, Seoul National University, Seoul 151-742, Korea.

${ }^{3}$ Embryo Technology and Stem Cell Research Center and School of Biotechnology, Suranaree University of Technology, Nakhon Ratchasima 30000, Thailand.

Submitted Sept. 19, 2012; Accepted Dec. 26, 2012; Revised Jan. 9, 2013
}

Furthermore, native cattle have higher heat tolerance, higher resistance to regional ectoparasitic diseases, and the ability to utilize low quality forages (FAO, 2006). In the last few decades, however, the numbers of the indigenous tropical cattle breeds as well as Thai native cattle have declined steeply, mainly due to lack of encouragement to maintain populations in the face of the threat posed by commercial breeds and modernization of agriculture (Department of Livestock Development of Thailand, 2011). Therefore, there is an urgent need to protect and propagate the Thai native cattle in order to increase the population in a shorter period of time, preserve the genetic resources and diversity of this and other native breeds.

An increase in the population of endangered mammalian species can benefit from modern reproductive biotechnologies including artificial insemination (AI), multiple ovulation and embryo transfer (MOET) and in vitro embryo production (IVP) (Galli et al., 2003). To date, the OPU method is a modern technique for recovery of cumulus-oocyte complexes (COCs) from live donors for IVP (OPU-IVP system) (Galli et al., 2001). Because of the 


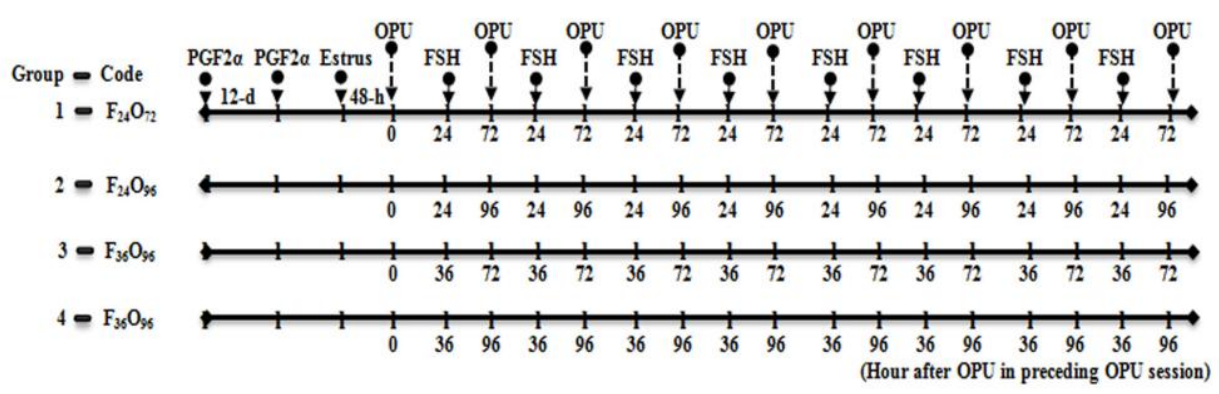

Figure 1. Superstimulation protocols for repeated OPU in Thai native cattle.

urgent need to increase the population of native cattle in a shorter period of time, the exogenous administration of gonadotropins with OPU has become the preferred method to increase the number of follicles available for aspiration. Of the different hormones that were used, such as GnRH (Kohram et al., 1998), FSH (Reis et al., 2002), eCG (Sendag et al., 2008) and PMSG (Pieterse et al., 1992), FSH has usually given the best results in terms of number of follicles aspirated and oocytes retrieved. Furthermore, it has been used successfully in IVP from superstimulation of follicular growth with OPU techniques in Angus crossbreed cows (Chaubal et al., 2006; Chaubal et al., 2007), Holstein cows (De Roovera et al., 2005), Simmental heifers (Reis et al., 2002) and Nellore cattles (Monteiro et al., 2010).

In Thai native cattle, the number of studies on superstimulation of ovarian follicular growth and follicular aspiration is limited. Furthermore, Thai native cattle differ considerably from B. taurus and some breeds of B. indicus in ovarian follicular dynamics (Sakhong et al., 2011). Therefore, data reported for B. taurus or some breeds of $B$. indicus should not be extrapolated to Thai native cattle. Moreover, there is a paucity of data on the efficacy of ovarian follicular stimulation by a single dose of FSH before oocyte retrieval to avoid the stress related to repeat handling in Thai native cattle. Thus, the objective of this study was to evaluate the effectiveness of a single administration of FSH for superstimulation of ovarian follicular growth and to evaluate the best time for superstimulation and oocyte retrieval in Thai native heifers undergoing repeated superstimulation and OPU.

\section{MATERIAL AND METHODS}

\section{Experimental animals}

This study was performed at the beef cattle farm, Department of Animal Science, Faculty of Agriculture, Khon Kaen University, Khon Kaen, Thailand (Latitude $16^{\circ} 26^{\prime} \mathrm{N}$, Longitude $102^{\circ} 50^{\prime} \mathrm{E}$, altitude $163 \mathrm{~m}$ ). During the past $30 \mathrm{yr}$, the mean annual temperature has been $27.21^{\circ} \mathrm{C}$ and the mean temperatures for the hottest and coldest months have been 31.53 and $21.89^{\circ} \mathrm{C}$ (TMD, 2005).

The animals used were nulliparous, cyclic heifers and free from reproductive abnormalities $(n=20)$; they were kept on pasture (Panicum maximum) in the winter to the rainy season from January until August, with a diet of $83 \%$ corn and $17 \%$ soybean supplementation $(1 \mathrm{~kg} / \mathrm{head} / \mathrm{d})$. The mean body weight, age and body condition score of heifers was $178.40 \pm 5.0 \mathrm{~kg}$ (ranging from 170 to $185 \mathrm{~kg}$ ), $2.35 \pm$ $0.15 \mathrm{yr}$ (ranging from 2.2 to $2.5 \mathrm{yr}$ ) and $4.00 \pm 0.5$ (3.5 to 4.5 on a 0 to 5 point scale) (Lowman et al., 1976).

\section{Experimental design and superstimulation protocol}

The research protocol was approved by the Animal Ethical Committee of Khon Kaen University, Thailand. In the randomized complete block design, Thai native heifers $(n=20)$ were divided into four groups of five heifers per group based on the average follicular numbers in the estrus cycle of each heifer from the preliminary study. Each group was allotted to a treatment protocol; all heifers were subjected to eight sequential sessions of OPU. Treatments and the experimental design are explained below and summarized in Figure 1.

Before the first aspiration, the heifers were synchronized in estrus and the dominant follicle removed according to the method previously described by Viana et al. (2010). Briefly, the heifers in all groups were synchronized in estrus by injecting $500 \mu \mathrm{g}$ prostaglandin F2 $\alpha$ (PGF2 $\alpha$ ) (500 $\mu \mathrm{g}$ Cloprostenol, Estrumate, Coopers, Berkhamsted, England) twice at an interval of $12 \mathrm{~d}$ and the estrous was observed every $12 \mathrm{~h}$ after last PGF $2 \alpha$ treatment. All follicles $\geq 5 \mathrm{~mm}$ in diameter were ablated in the first OPU at a $48 \mathrm{~h}$ interval after estrus but before ovulation to avoid corpus luteum (CL) development and this was designated as $0 \mathrm{~h}$ for this experiment. The absence of a CL at the beginning of the experimental period was confirmed by ultrasonography and blood serum progesterone (P4) detection.

This first OPU was performed only to ablate the dominant follicles present at the start of the experiment and the remaining eight OPU sessions after superstimulation to detect follicular growth in each group and to evaluate the number and quality of recovered COCs. Follicular dynamics were monitored in each session of OPU. The 
OPU outcomes were recorded independently, according to the development of dominant or sub-dominant follicles in the interval preceding each aspiration procedure.

\section{Superstimulation protocol in Group $1\left(\mathbf{F}_{24} \mathbf{O}_{72}\right)$}

Heifers were given $100 \mathrm{mg}$ of FSH (Folltropin ${ }^{\circledR}-\mathrm{V}$ ) dissolved in $10 \mathrm{ml}$ of $30 \%$ (wt/vol) polyvinylpyrrolidone (PVP) to form FSHp (Chasombat and Vongpralub, 2011) by a single dose administration $24 \mathrm{~h}$ after follicular ablation. All OPU sessions were performed at $72 \mathrm{~h}$ after follicular aspiration and were assigned to the $\mathrm{F}_{24} \mathrm{O}_{72}$ protocol code. A $24 \mathrm{~h}$ interval after the preceding OPU session was the time set for superstimulation of follicular growth for the subsequent OPU session over a period of eight OPU sessions.

\section{Superstimulation protocol in Group $2\left(\mathrm{~F}_{24} \mathrm{O}_{96}\right)$}

In this group, the treatment regimen was the same as in Group 1, except that all OPU sessions were performed at 96 $\mathrm{h}$ after follicular ablation and were assigned to the $\mathrm{F}_{24} \mathrm{O}_{96}$ protocol code.

\section{Superstimulation protocol in Group $3\left(\mathbf{F}_{36} \mathbf{O}_{72}\right)$}

Heifers were given $100 \mathrm{mg}$ of FSHp by a single dose administration at $36 \mathrm{~h}$ after follicular ablation; all OPU sessions were performed at $72 \mathrm{~h}$ after follicular ablation and were assigned to the $\mathrm{F}_{36} \mathrm{O}_{72}$ protocol code. A $36 \mathrm{~h}$ interval after the preceding OPU session was the time set for superstimulation of follicular growth for the subsequent OPU session over a period of eight OPU sessions.

\section{Superstimulation protocol in Group $4\left(\mathrm{~F}_{36} \mathbf{O}_{96}\right)$}

In this group, the treatment regimen was the same as in Group 3, except that all OPU sessions were performed at 96 $\mathrm{h}$ after follicular ablation and were assigned to the $\mathrm{F}_{36} \mathrm{O}_{96}$ protocol code.

\section{Characterization of follicular dynamics and deviation}

Follicular dynamics were observed during eight consecutive aspiration intervals, beginning $12 \mathrm{~h}$ after each OPU session. The ovaries were examined with a portable ultrasound device equipped with a trans-rectal linear-array 7.5-MHz transducer (Scanner Honda ${ }^{\circledR} \mathrm{HS}-2000$, Honda Electronics Co., Ltd. Japan). The sonograms from ultrasonographic scanning of both ovaries were recorded in the ultrasound machine at examination. Evaluations were performed at the first OPU session or zero hour (h 0 ) of the experiment protocols and twice daily (every $12 \mathrm{~h}$ ) after the start of the experiment over the eight OPU sessions. At each examination, the size and location of all follicles were recorded on a sketch of each ovary. The first, second, and third largest follicles were defined as F1, F2, and F3 based on individual retrospective determinations of maximum follicular diameters. Follicles with a diameter $\geq 7 \mathrm{~mm}$ were considered dominant, based on previous reports in Thai native heifers (Chasombat and Vongpralub, 2011; Sakhong et al., 2011). The evaluations of follicular deviations were performed as previously described by Gimenes et al. (2008). Briefly, follicular deviations after follicular ablation was determined by comparing F1, F2 and F3 diameters and are designated as observed deviations. The evaluations of ovarian follicular dynamics were performed as previously described by Sartori et al. (2001). Briefly, the data of follicular dynamics after follicular aspiration were normalized to the beginning of deviation in follicular growth of F1, F2 and F3.

\section{Follicular aspiration and oocytes recovery}

The follicular aspirations were performed according to the method previously described by Bols et al. (1997). Briefly, the animals were restrained in a suitably designed stanchion, which allowed minimal movement and prepared for OPU by administering $0.02 \mathrm{mg} / \mathrm{kg}$ BW Xylazine HCL (Xylaxin, L.B.S. Laboratory Ltd., Bangkok, Thailand) i.m. followed $10 \mathrm{~min}$ later with an epidural anesthesia of 3 to 4 $\mathrm{ml}$ of 2\% lignocaine HCL (Xylocaine 2\%, Union drug laboratories Ltd., Bangkok, Thailand). The follicle aspiration was performed with a portable ultrasound device equipped with a sector intravaginal $7.5-\mathrm{MHz}$ transducer (Honda ${ }^{\circledR}$ HS-2000, Honda Electronics Co., Ltd, Japan), and used with a $17 \mathrm{G} \times 490 \mathrm{~mm}$ sterile stainless cow ova vacuum needle (COVA Needle; Misawa Medical, Tokyo, Japan). An aspiration pump (Vakuum pumpe; Minitüb $\mathrm{GmbH}$, Tiefenbach, Germany) created a vacuum of $120 \mathrm{mmHg}$ and $22 \mathrm{ml} / \mathrm{min}$ aspiration rate through a disposable aspiration needle. All follicles $\geq 3 \mathrm{~mm}$ were aspirated; specific attention was given to avoid partial aspiration or completely missing a follicle. Numbers of follicles in the 2 to $3 \mathrm{~mm}, 4$ to $6 \mathrm{~mm}$ and $\geq 7 \mathrm{~mm}$ diameter categories were recorded (Chasombat and Vongpralub, 2011; Sakhong et al., 2011). The aspirated follicular fluid was collected in 50-ml tubes containing modified Dulbecco's phosphate buffered saline (mDPBS), supplemented with $1 \%$ fetal calf serum (Gibco) and $125 \mathrm{IU} / \mathrm{ml}$ heparin (Sigma). Recovered COCs were morphologically classified into five categories according to those previously described by Chaubal et al. (2006), as follows: Grade A, >4 layers of cumulus cells; Grade B, three or four layers of cumulus cells; Grade C, one or two layers of cumulus cells; Grade D, denuded oocytes; and Grade E, oocytes with expanded cumulus. All COCs (including Grades A-C) from each cow were used for maturation except Grades D and E which were not used for IVP.

\section{Blood collection and hormonal assay}

Blood samples were collected from the animals by coccygeal artery puncture, using $15 \mathrm{ml}$ vacutainer tubes 
containing heparin at zero hour of first OPU just before the start of treatment, and every $12 \mathrm{~h}$ after initiation of treatment over the period of eight OPU sessions in all treatment groups. Immediately after collection, the samples were centrifuged at $2,000 \times \mathrm{g}$ for $20 \mathrm{~min}$, and the plasma obtained was marked and stored at $-20^{\circ} \mathrm{C}$ pending hormonal analysis. In order to determine possible differences between treatment group, blood samples were analyzed to determine hormone profiles of each OPU session. The analyses were performed by the double-antibody radioimmunoassay (DARIA) technique for determination of follicle stimulating hormone (FSH), progesterone (P4) and oestradiol (E2), as described previously (McNeilly and Fraser, 1987; Crowe et al., 1995; Mann et al., 1995) in the radioimmunoassay laboratory, Department of Radiology, Faculty of Medicine, Khon Kaen University, Thailand.

Plasma P4, E2 and FSH concentrations were measured without prior extraction, using an ${ }^{125} \mathrm{I}$-label for P4, E2 and FSH DARIA (McNeilly and Fraser, 1987; Crowe et al., 1995; Mann et al., 1995). For P4, sensitivity of an assay at an $80 \%$ effective dose (ED80), inter-assay coefficients of variation (CVITE's) for low-, medium- and high-quality controls was $0.35 \mathrm{ng} / \mathrm{ml}, 27.3 \%, 19.6 \%$ and $15.7 \%$, corresponding intra-assay coefficients of variation (CVITR's) were 17.4, 13.6 and 10.4\%. For E2, ED80, CVITE's for low-, medium- and high-quality controls was $0.195 \mathrm{pg} / \mathrm{ml}, 20.1 \%, 12.4 \%$ and $14.3 \%$, corresponding CVITR's were 12.5, 10.1 and $11.9 \%$. For FSH, ED80, CVITE's for low-, medium- and high-quality controls was $0.05 \mathrm{ng} / \mathrm{ml}, 14.2 \%, 9.17 \%$ and $10.23 \%$, corresponding CVITR's were $11.6,8.3$ and $9.16 \%$.

\section{IVM/IVF/IVC}

All Grades A-C oocytes from each heifer were matured using the procedure previously described (Ratto et al., 2011). Briefly, The COCs were washed three times with mDPBS, and twice in TCM-199 (Gibco) with 10\% FCS, and groups of 8-10 COCs were transferred immediately into $100 \mu \mathrm{l}$ droplets of maturation medium of TCM-199 (Gibco), that consisted of $10 \% \mathrm{FCS}, 10 \mu \mathrm{g} / \mathrm{ml} \mathrm{LH}$ (Sigma), $1 \mu \mathrm{g} / \mathrm{ml}$ E2 (Sigma), $0.5 \mu \mathrm{g} / \mathrm{ml} \mathrm{FSH} \mathrm{(Sigma)} 50 \mathrm{IU} / \mathrm{ml}$ penicillin G sodium (Sigma) and $50 \mathrm{mg} / \mathrm{ml}$ streptomycin (Sigma). The droplets containing oocytes were covered with mineral oil and then the Petri dishes were placed in the incubator at $38.5^{\circ} \mathrm{C}, 5 \% \mathrm{CO}_{2}$ in air at maximum humidity for $24 \mathrm{~h}$.

IVF sperm preparations were performed by the swim-up method as described previously (Parrish et al., 1995) with minor modifications. Briefly, two straws of frozen semen from a Thai native cattle bull, $0.25 \mathrm{ml} / \mathrm{straw}, 20$ million spermatozoa/straw, were thawed in warm $\left(37^{\circ} \mathrm{C}\right)$ water for $30 \mathrm{~s}$ and $200 \mu \mathrm{l}$ of semen were placed into $2 \mathrm{ml}$ of Tyrode's albumin lactate pyruvate-HEPES (TALP-HEPES) containing $0.3 \%(\mathrm{wt} / \mathrm{vol})$ bovine serum albumin (BSA; fatty acid-free) in a $15-\mathrm{ml}$ tube, and incubated at $39^{\circ} \mathrm{C}, 5 \% \mathrm{CO}_{2}$ and maximum humidity. After $1 \mathrm{~h}, 1 \mathrm{ml}$ of the upper fraction was collected and placed into $3 \mathrm{ml}$ of TALPHEPES, and centrifuged $(2,100 \times \mathrm{g}, 7 \mathrm{~min})$. The pellet was then re-suspended with $3 \mathrm{ml}$ TALP-HEPES and centrifugated for $7 \mathrm{~min}$ at $2,100 \times \mathrm{g}$. Afterwards the pellet was re-suspended in $150 \mu \mathrm{l}$ fertilization medium of TALPIVF containing $0.3 \%$ (wt/vol) fatty acid-free BSA, 3.0 $\mu \mathrm{g} / \mathrm{ml}$ heparin (Sigma), $3.0 \mu \mathrm{g} / \mathrm{ml}$ penicillamine (Sigma) and the final sperm concentration was adjusted to $1 \times 10^{6} / \mathrm{ml}$.

For IVF, twenty-four hours later, COCs were removed from the maturation medium and washed in TALP-HEPES medium. Excess cumulus cells were removed by gentle pipetting before groups of 10 to 15 oocytes were placed in 5 $\mu \mathrm{l}$ IVF-TALP medium and covered with mineral oil; a $95 \mu \mathrm{l}$ suspensions of frozen-thawed spermatozoa from the IVFTALP medium of sperm preparations was then added. Spermatozoa and oocytes were co-incubated for 18 to $20 \mathrm{~h}$ at $38.5^{\circ} \mathrm{C}$ in an atmosphere of $5 \% \mathrm{CO}_{2}$ in air at maximum humidity.

The zygotes were cultured in synthetic oviductal fluid with a minor modification (mSOF) (Holm et al., 1999). Briefly, approximately 18 to $20 \mathrm{~h}$ after insemination, the zygotes were washed four times in PBS and once in $\mathrm{mSOF}$ which consisted of $0.5 \mu \mathrm{g} / \mathrm{ml}$ glutamine (Sigma), $3 \mathrm{mg} / \mathrm{ml}$ BAS (G-mSOF) without glucose and citrate. Subsequently, the zygotes were transferred immediately into $100 \mu \mathrm{l}$ droplets of G-mSOF covered with mineral oil and cultured for $28 \mathrm{~h}$ ( $\mathrm{d} 1$ to 2 ) at $38.5^{\circ} \mathrm{C}$ in an atmosphere of $5 \% \mathrm{CO}_{2}$ in air at maximum humidity. The cleavage rates were checked $48 \mathrm{~h}$ post insemination under stereo zoom microscopy. After that, the embryos (two cell stage or beyond) were washed twice in the mSOF which consisted of $0.5 \mu \mathrm{g} / \mathrm{ml}$ glucose (Sigma), $1 \mu \mathrm{g} / \mathrm{ml}$ citrate (Sigma), $3 \mathrm{mg} / \mathrm{ml}$ BAS (C-mSOF) without glutamine. The embryos were transferred immediately into $100 \mu \mathrm{l}$ droplets of $\mathrm{C}$-mSOF with bovine oviductal epithelial cells covered with mineral oil and cultured for another $6 \mathrm{~d}$ at $38.5^{\circ} \mathrm{C}$ in an atmosphere of $5 \%$ $\mathrm{CO}_{2}$ in air at maximum humidity and the culture medium was replaced with fresh medium every day. Every day, embryos were examined under an inverted microscope to evaluate development. On d 8, the percentage of good quality transferable blastocysts (BL) grade 1 and 2 (Lindner et al., 1983) were recorded. The cleavage, 8-cell, 16-cell and blastocysts rate was calculated on the basis of number of oocytes cultured.

\section{Statistical analysis}

These studies were done with completely randomized designs with repeated measures (eight OPU sessions). Data 
Table 1. Ovarian follicular development (Mean \pm SEM) after undergoing repeated superstimulation of ovarian follicular growth and OPU in Thai native heifers

\begin{tabular}{lcccc}
\hline Protocol code (Group)* & $\mathrm{F}_{24} \mathrm{O}_{72}$ (Group 1) & $\mathrm{F}_{24} \mathrm{O}_{96}(\mathrm{Group} 2)$ & $\mathrm{F}_{36} \mathrm{O}_{72}(\mathrm{Group} 3)$ & $\mathrm{F}_{36} \mathrm{O}_{96}(\mathrm{Group} 4)$ \\
\hline Number of animals (n) & 5 & 5 & 5 & 5 \\
Follicular population at the end of OPU sessions & $15.65 \pm 2.45^{\mathrm{a}}$ & $15.38 \pm 2.65^{\mathrm{a}}$ & $22.75 \pm 3.21^{\mathrm{b}}$ & $22.58 \pm 3.17^{\mathrm{b}}$ \\
Initial diameter (mm) & & & & \\
$\quad$ F1 & $3.49 \pm 0.12$ & $3.45 \pm 0.09$ & $3.60 \pm 0.11$ & $3.47 \pm 0.10$ \\
*F2 & $2.80 \pm 0.11$ & $2.85 \pm 0.19$ & $2.96 \pm 0.14$ & $2.89 \pm 0.12$ \\
*F3 & $2.16 \pm 0.06$ & $2.23 \pm 0.08$ & $2.23 \pm 0.11$ & $2.21 \pm 0.09$ \\
Maximum diameter (mm) & & & \\
F1 & $5.92 \pm 0.13^{\mathrm{c}}$ & $7.80 \pm 0.15^{\mathrm{ab}}$ & $6.95 \pm 0.17^{\mathrm{bc}}$ & $8.82 \pm 0.12^{\mathrm{a}}$ \\
F2 & $5.12 \pm 0.13^{\mathrm{c}}$ & $5.76 \pm 0.12^{\mathrm{b}}$ & $5.66 \pm 0.16^{\mathrm{bc}}$ & $6.84 \pm 0.18^{\mathrm{a}}$ \\
F3 & $3.45 \pm 0.11^{\mathrm{c}}$ & $3.93 \pm 0.10^{\mathrm{b}}$ & $4.41 \pm 0.14^{\mathrm{a}}$ & $4.45 \pm 0.10^{\mathrm{a}}$ \\
Growth rate (mm/d) & & & \\
F1 & $1.97 \pm 0.09^{\mathrm{b}}$ & $1.95 \pm 0.11^{\mathrm{b}}$ & $2.30 \pm 0.10^{\mathrm{a}}$ & $2.20 \pm 0.08^{\mathrm{a}}$ \\
F2 & $1.70 \pm 0.12^{\mathrm{a}}$ & $1.44 \pm 0.04^{\mathrm{b}}$ & $1.88 \pm 0.06^{\mathrm{a}}$ & $1.46 \pm 0.10^{\mathrm{b}}$ \\
F3 & $1.25 \pm 0.07^{\mathrm{b}}$ & $1.00 \pm 0.03^{\mathrm{c}}$ & $1.47 \pm 0.04^{\mathrm{a}}$ & $1.10 \pm 0.02^{\mathrm{c}}$ \\
\hline
\end{tabular}

$\overline{\mathrm{a}, \mathrm{b}, \mathrm{c}, \mathrm{d}}$ Values followed by different superscripts within rows differ $(\mathrm{p} \leq 0.05)$.

*F1: largest follicles, *F2 sub-largest follicles, *F3: largest subordinated follicle. * Protocol code (Group), a single dose i.m. administration of $100 \mathrm{mg}$ FSHp at $24 \mathrm{~h}$ and OPU at $72\left(\mathrm{~F}_{24} \mathrm{O}_{72}\right.$; Group 1) or $96 \mathrm{~h}\left(\mathrm{~F}_{24} \mathrm{O}_{96}\right.$; Group 2), and a single dose i.m. administration of $100 \mathrm{mg}$ FSHp at $36 \mathrm{~h}$ and OPU at 72 $\left(\mathrm{F}_{36} \mathrm{O}_{72}\right.$; Group 3) or $96 \mathrm{~h}\left(\mathrm{~F}_{36} \mathrm{O}_{96} ;\right.$ Group 4) after follicular ablation.

obtained during the experiments were analyzed using the mixed model procedure of Statistical Analysis System software (SAS) (SAS, 1998). The models included treatment effect and time (OPU sessions). Protected least significance differences were used to compare least square (LS) means. Significant differences between treatment groups were declared at $\mathrm{p} \leq 0.05$.

\section{RESULTS}

\section{Characterization of follicular dynamics and deviation}

The main characteristics of the ovarian follicular dynamics after follicular ablation in all treatment groups are shown in Table 1. The total follicular numbers at the end of OPU session in $\mathrm{F}_{36} \mathrm{O}_{72}$ (Group 3) and $\mathrm{F}_{36} \mathrm{O}_{96}$ (Group 4) protocol were higher than in the other two groups $(\mathrm{p}<0.05)$. Meanwhile, there was an effect of interval between OPU sessions on maximum diameter (mm) of F1, F2 and F3 follicles $(\mathrm{p}<0.05)$; in long intervals between OPU sessions they were bigger while in short interval between OPU sessions they were smaller. The growth rates $(\mathrm{mm} / \mathrm{d})$ of $\mathrm{F} 1$ in $\mathrm{F}_{36} \mathrm{O}_{72}$ (Group 3) and $\mathrm{F}_{36} \mathrm{O}_{96}$ (Group4) protocol were faster than $\mathrm{F}_{24} \mathrm{O}_{72}$ (Group 1) and $\mathrm{F}_{24} \mathrm{O}_{96}$ (Group 2) protocol $(\mathrm{p}<0.05)$. In addition, there was an effect of pre-ovulatory size $(\mathrm{F} 1)$ on growth rate $(\mathrm{mm} / \mathrm{d})$ of $\mathrm{F} 2$ and $\mathrm{F} 3$ follicles $(\mathrm{p}<0.05)$; the larger the maximum diameter of $\mathrm{F} 1$ follicles, the slower the growth rate in F2 and F3 follicles and vice versa.

The evaluation of the graphic representation of follicular diameter data enabled characterization of various follicular growth patterns according to F1, F2 and F3 deviations after follicular aspiration in each OPU intervals
(Figure 2). The follicle recruitment commenced at $24 \mathrm{~h}$ after follicular ablation in all treatment groups. Meanwhile, F1, F2 and F3 follicles $>4 \mathrm{~mm}$ were unobserved at $24 \mathrm{~h}$ after follicular ablation in all treatment groups (Figure 2). Furthermore, the dominant follicle selection occurred at 48 after follicular ablation and there was a significant difference in diameter of F1, F2 and F3 ( $p<0.05)$ follicles among the groups at this time. After that, the F1 follicles rapidly increased in size and showed a larger maximum diameter at the end of the OPU sessions than F2 and F3 in all group treatment protocols $(\mathrm{p}<0.05)$.

\section{Follicular aspiration and oocytes recovery}

This study consisted of a single dose i.m. administration of $100 \mathrm{mg}$ FSHp at $24 \mathrm{~h}$ and OPU at $72 \mathrm{~h}\left(\mathrm{~F}_{24} \mathrm{O}_{72}\right.$ protocol; Group 1) or $96 \mathrm{~h}\left(\mathrm{~F}_{24} \mathrm{O}_{96}\right.$ protocol; Group 2) and a single dose i.m. administration of $100 \mathrm{mg}$ FSHp at $36 \mathrm{~h}$ and OPU at $72 \mathrm{~h}\left(\mathrm{~F}_{36} \mathrm{O}_{72}\right.$ protocol; Group 3) or $96 \mathrm{~h}\left(\mathrm{~F}_{36} \mathrm{O}_{96}\right.$ protocol; Group 4) after follicular ablation. A total of 629, 615, 910 and 903 follicles were aspirated during 40 OPU sessions in $\mathrm{F}_{24} \mathrm{O}_{72}$ (Group 1), $\mathrm{F}_{24} \mathrm{O}_{96}$ (Group 2), $\mathrm{F}_{36} \mathrm{O}_{72}$ (Group 3) and $\mathrm{F}_{36} \mathrm{O}_{96}$ (Group 4) protocol, yielding 506, 541, 834 and 830 oocytes. The total number, mean and COC classifications are shown in Table 2. The mean number of aspirated follicles /heifer/session over a period of 8 OPU sessions in $\mathrm{F}_{36} \mathrm{O}_{72}$ (Groups 3) and $\mathrm{F}_{36} \mathrm{O}_{96}$ (Group 4) protocol were higher than $\mathrm{F}_{24} \mathrm{O}_{72}$ (Group 1) and $\mathrm{F}_{24} \mathrm{O}_{96}$ (Group 2) protocol $(\mathrm{p}<0.05)$, and no differences were shown when comparison were made between $\mathrm{F}_{24} \mathrm{O}_{72}$ (Group1) vs. $\mathrm{F}_{24} \mathrm{O}_{96}$ (Group 2) or $\mathrm{F}_{36} \mathrm{O}_{96}$ (Group 3) vs. $\mathrm{F}_{36} \mathrm{O}_{96}$ (Group 4) protocols. 


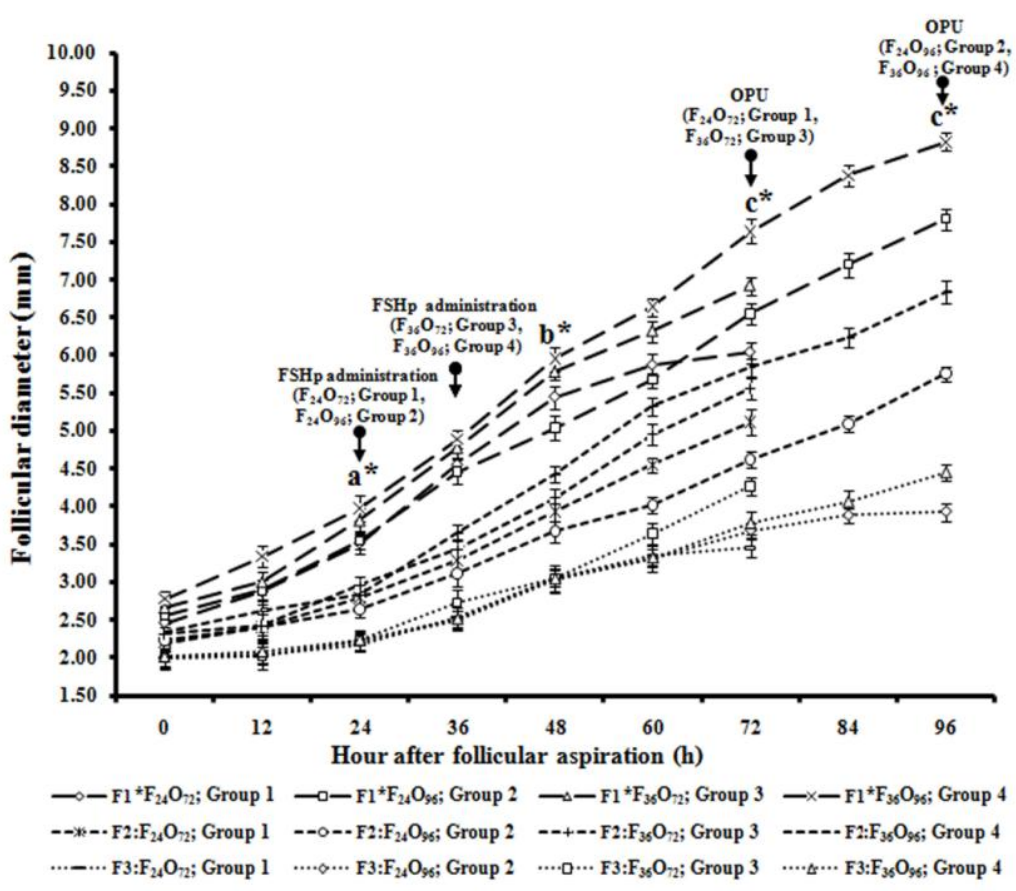

Figure 2. Ovarian follicular dynamics after follicular aspiration under repeated superstimulation of ovarian follicular growth and OPU in Thai native heifer. * Protocol code (Group), a single dose i.m. administration of $100 \mathrm{mg} \mathrm{FSHp} \mathrm{at} 24 \mathrm{~h}$ and OPU at $72\left(\mathrm{~F}_{24} \mathrm{O}_{72}\right.$; Group 1) or $96 \mathrm{~h}\left(\mathrm{~F}_{24} \mathrm{O}_{96}\right.$; Group 2), and a single dose i.m. administration of $100 \mathrm{mg} \mathrm{FSHp}$ at $36 \mathrm{~h}$ and OPU at $72\left(\mathrm{~F}_{36} \mathrm{O}_{72}\right.$; Group 3$)$ or $96 \mathrm{~h}$ $\left(\mathrm{F}_{36} \mathrm{O}_{96}\right.$; Group 4) after follicular ablation. Each dot represents mean \pm SEM. Follicles are identified by maximum attained diameter as $\mathrm{F} 1 *$ : largest follicles, F2* coordinate follicle and F3*: subordinated follicle. Values with asterisk $(*)$ indicate significant differences in follicular diameter of F1, F2 or F3 at the time of beginning deviation (a), dominance follicle selection (b) and end of OPU session (c) after follicular aspiration among groups $(\mathrm{p}<0.05)$.

Table 2. Total number and mean values (Mean \pm SEM) of recovered COCs and classification of COCs collected undergoing repeated superstimulation of ovarian follicular growth and OPU in Thai native heifers

\begin{tabular}{|c|c|c|c|c|}
\hline Protocol code (Group)* & $\mathrm{F}_{24} \mathrm{O}_{72}$ (Group 1) & $\mathrm{F}_{24} \mathrm{O}_{96}$ (Group 2) & $\mathrm{F}_{36} \mathrm{O}_{72}$ (Group 3) & $\mathrm{F}_{36} \mathrm{O}_{96}$ (Group 4) \\
\hline Number of animals (n) & 5 & 5 & 5 & 5 \\
\hline \multicolumn{5}{|l|}{ Characteristics } \\
\hline Total number of aspiration sessions & 40 & 40 & 40 & 40 \\
\hline Number of aspiration sessions (/heifer) & 8 & 8 & 8 & 8 \\
\hline Total number of aspirated follicles & 629 & 615 & 910 & 903 \\
\hline Mean number of aspirated follicles (/heifer/session) & $15.73 \pm 2.46^{\mathrm{b}}$ & $15.38 \pm 2.29^{\mathrm{b}}$ & $22.75 \pm 2.56^{\mathrm{a}}$ & $22.58 \pm 2.12^{\mathrm{a}}$ \\
\hline \multicolumn{5}{|l|}{ Categories of follicles at aspiration (/heifer/session) } \\
\hline $2-3 \mathrm{~mm}$ & $5.70 \pm 1.03^{\mathrm{a}}$ & $0.18 \pm 0.02^{\mathrm{c}}$ & $6.95 \pm 1.45^{\mathrm{a}}$ & $0.68 \pm 0.06^{\mathrm{b}}$ \\
\hline $4-6 \mathrm{~mm}$ & $9.65 \pm 1.12^{\mathrm{b}}$ & $9.95 \pm 1.59^{\mathrm{b}}$ & $14.20 \pm 2.17^{\mathrm{a}}$ & $14.75 \pm 2.05^{\mathrm{a}}$ \\
\hline$>7 \mathrm{~mm}$ & $0.30 \pm 0.03^{\mathrm{d}}$ & $5.25 \pm 0.10^{\mathrm{b}}$ & $1.60 \pm 0.06^{\mathrm{c}}$ & $7.15 \pm 1.04^{\mathrm{a}}$ \\
\hline Total number of recovered oocytes & 506.0 & 541.0 & 834.0 & 830.0 \\
\hline Recovery rate $(\%)$ & $80.83 \pm 2.68^{\mathrm{d}}$ & $87.97 \pm 2.89^{\mathrm{bc}}$ & $91.65 \pm 3.03^{\mathrm{a}}$ & $89.25 \pm 2.54^{\mathrm{ab}}$ \\
\hline Mean number of oocytes/heifer/session & $12.65 \pm 1.23^{\mathrm{b}}$ & $13.53 \pm 1.28^{\mathrm{b}}$ & $20.85 \pm 2.0^{\mathrm{a}}$ & $20.75 \pm 2.04^{\mathrm{a}}$ \\
\hline \multicolumn{5}{|l|}{ Oocytes categories } \\
\hline A/Total (\%) & $82 / 506(16.21)^{\mathrm{b}}$ & $54 / 541(9.8)^{\mathrm{d}}$ & $222 / 834(26.62)^{\mathrm{a}}$ & $120 / 830(14.46)^{\mathrm{c}}$ \\
\hline $\mathrm{B} /$ Total $(\%)$ & $142 / 506(28.06)^{\mathrm{a}}$ & $104 / 541(19.22)^{\mathrm{c}}$ & $221 / 834(26.50)^{\mathrm{b}}$ & $145 / 830(17.47)^{\mathrm{d}}$ \\
\hline C/Total (\%) & $214 / 506(42.29)^{\mathrm{a}}$ & $107 / 541(19.78)^{\mathrm{c}}$ & $276 / 834(11.27)^{\mathrm{d}}$ & $170 / 830(20.48)^{\mathrm{b}}$ \\
\hline D: Degenerated COCs or oocytes (\%) & $68 / 506(13.44)^{\mathrm{b}}$ & $112 / 541(20.70)^{\mathrm{a}}$ & $94 / 834(11.27)^{\mathrm{c}}$ & $174 / 830(20.96)^{\mathrm{a}}$ \\
\hline E: Expanded COCs $(\%)$ & $0 / 506(0.00)^{\mathrm{d}}$ & $164 / 541(30.31)^{\mathrm{a}}$ & $21 / 834(2.52)^{\mathrm{c}}$ & $221 / 830(26.63)^{\mathrm{b}}$ \\
\hline
\end{tabular}

$\overline{\mathrm{a}, \mathrm{b}, \mathrm{c}, \mathrm{d}}$ Values followed by different superscripts within rows differ $(\mathrm{p}<0.05)$.

*Protocol code (Group), a single dose i.m. administration of $100 \mathrm{mg} \mathrm{FSHp}$ at $24 \mathrm{~h}$ and OPU at $72\left(\mathrm{~F}_{24} \mathrm{O}_{72}\right.$; Group 1) or 96 h ( $\mathrm{F}_{24} \mathrm{O}_{96}$; Group 2), and a single dose i.m. administration of $100 \mathrm{mg}$ FSHp at $36 \mathrm{~h}$ and OPU at $72\left(\mathrm{~F}_{36} \mathrm{O}_{72}\right.$; Group 3$)$ or $96 \mathrm{~h}\left(\mathrm{~F}_{36} \mathrm{O}_{96}\right.$; Group 4) after follicular ablation. 
The follicle size categories in all treatment groups are shown in Table 2. The number of small follicles ( 2 to $3 \mathrm{~mm}$ in diameter) in $\mathrm{F}_{24} \mathrm{O}_{72}$ (Groups 1) and $\mathrm{F}_{36} \mathrm{O}_{72}$ (Group 3) protocol were higher than $\mathrm{F}_{24} \mathrm{O}_{96}$ (Groups 2) and $\mathrm{F}_{36} \mathrm{O}_{96}$ (Group 4) protocol whereas, the number of medium follicles (4 to $6 \mathrm{~mm}$ in diameter) in $\mathrm{F}_{36} \mathrm{O}_{72}$ (Groups 3) and $\mathrm{F}_{36} \mathrm{O}_{96}$ (Group 4) were higher than $\mathrm{F}_{24} \mathrm{O}_{72}$ (Groups 1) and $\mathrm{F}_{24} \mathrm{O}_{96}$ (Group 2) protocol $(\mathrm{p}<0.05)$. The largest number of larger follicles ( $>7 \mathrm{~mm}$ in diameter) was found in $\mathrm{F}_{36} \mathrm{O}_{96}$ (Group 4) followed by $\mathrm{F}_{24} \mathrm{O}_{96}$ (Group 2) protocol and both groups were higher than $\mathrm{F}_{24} \mathrm{O}_{72}$ (Groups 1) and $\mathrm{F}_{36} \mathrm{O}_{72}$ (Group 3) protocols $(\mathrm{p}<0.05)$.

The mean number of recovered oocytes/heifer/session in $\mathrm{F}_{36} \mathrm{O}_{72}$ (Groups 3) and $\mathrm{F}_{36} \mathrm{O}_{96}$ (Group 4) protocols were higher than $\mathrm{F}_{24} \mathrm{O}_{72}$ (Group 1) and $\mathrm{F}_{24} \mathrm{O}_{96}$ (Group 2) protocol $(p<0.05)$, whereas, there was no difference between $\mathrm{F}_{24} \mathrm{O}_{72}$ (Groups 1) vs. $\mathrm{F}_{24} \mathrm{O}_{96}$ (Group 2) protocol and $\mathrm{F}_{36} \mathrm{O}_{96}$ (Group 3) vs. $\mathrm{F}_{36} \mathrm{O}_{96}$ (Group 4) protocol. The oocyte recovery rate, defined as the percentage of COCs recovered per total number of aspirated follicles, in $\mathrm{F}_{36} \mathrm{O}_{96}$ (Group 3) protocol was higher than in the other groups $(\mathrm{p}<0.05)$.

The distributions of oocytes according to morphological grades, as a percentage of total oocytes retrieved, are presented in Table 2. The $\mathrm{F}_{36} \mathrm{O}_{96}$ (Group 3) protocol generated more $(\mathrm{p}<0.05)$ grade $\mathrm{A}, \mathrm{B}$ and $\mathrm{C}$ oocytes, as compared to $\mathrm{F}_{24} \mathrm{O}_{72}$ (Groups 1), $\mathrm{F}_{24} \mathrm{O}_{96}$ (Group 2) and $\mathrm{F}_{36} \mathrm{O}_{96}$ (Group 4) protocols. Moreover, the percentage of degenerated COCs (D) and expanded COCs (E) in $\mathrm{F}_{36} \mathrm{O}_{96}$ (Group 3) protocol was lower than in $\mathrm{F}_{24} \mathrm{O}_{96}$ (Group 2) and $\mathrm{F}_{36} \mathrm{O}_{96}$ (Group 4) protocol, but was higher than $\mathrm{F}_{24} \mathrm{O}_{72}$ (Groups 1) protocol $(\mathrm{p}<0.05)$, whereas, the number of COCs in Grade D and $\mathrm{E}$ was higher in $\mathrm{F}_{36} \mathrm{O}_{96}$ (Group 4) protocol than in the other groups $(\mathrm{p}<0.05)$.

\section{Hormone profile}

The hormone profiles of FSH, E2 and P4 after follicular aspiration following superstimulation of ovarian follicular growth and repeated OPU throughout eight OPU session periods are presented in Figures 3A, 3B. As shown in Figure 3A, the concentrations of FSH remained low $(<0.6$ $\mathrm{ng} / \mathrm{ml}$ ) until $24 \mathrm{~h}$ after follicular aspiration in all treatment groups. In fact, at $24 \mathrm{~h}$ after follicular aspiration, the circulatory FSH concentrations in the $\mathrm{F}_{24} \mathrm{O}_{72}$ (Groups 1) protocol were lower than in any other three Groups (p<0.05). In $\mathrm{F}_{24} \mathrm{O}_{72}$ (Groups 1)and in the $\mathrm{F}_{24} \mathrm{O}_{96}$ (Group 2) protocol after FSHp treatment the circulatory FSH concentrations sharply increased until 72 h (Group 1) or 96 $h$ (Group 2). Nevertheless, the maintenance level was lower than in $\mathrm{F}_{36} \mathrm{O}_{96}$ (Group 3) or $\mathrm{F}_{36} \mathrm{O}_{96}$ (Group 4) protocol $(\mathrm{p}<0.05)$.

The circulatory FSH concentrations surged quickly from 24 to $36 \mathrm{~h}(>0.8 \mathrm{ng} / \mathrm{ml})$ (Figure 3A) after follicular ablation in all group treatment protocols. At $36 \mathrm{~h}$ after follicular ablation, the concentration of $\mathrm{FSH}$ in $\mathrm{F}_{36} \mathrm{O}_{96}$ (Group 4) protocol was higher than any other three group $(\mathrm{p}<0.05)$. Moreover, after FSHp administration the circulatory FSH concentrations were sharply increased and were maintained at a higher level in $\mathrm{F}_{36} \mathrm{O}_{96}$ (Group 3) and $\mathrm{F}_{36} \mathrm{O}_{96}$ (Group 4) protocols than in $\mathrm{F}_{24} \mathrm{O}_{72}$ (group 1) and $\mathrm{F}_{24} \mathrm{O}_{96}$ (Group 2) protocols $(\mathrm{p}<0.05)$.

The estrogen concentrations in plasma were maintained at a lower level $(<0.08 \mathrm{pg} / \mathrm{ml}) 12$ to $36 \mathrm{~h}$ after follicular ablation in all treatment protocol groups (Figure 3B). Thereafter, there were sharp increases from $36 \mathrm{~h}$ until OPU in all treatment protocol groups corresponding with the beginning of follicular deviation at $24 \mathrm{~h}$ after follicular ablation (Figure 2). Nevertheless, the circulatory levels of E2 from 36 to $72 \mathrm{~h}$ in the $\mathrm{F}_{36} \mathrm{O}_{72}$ protocol (Group 3) were higher than in $\mathrm{F}_{24} \mathrm{O}_{72}$ protocol (Group 1) but were maintained at a level lower than in $\mathrm{F}_{36} \mathrm{O}_{96}$ protocol (Group 4) $(p<0.05)$. Meanwhile, the circulating levels of $E 2$ from 36 to $96 \mathrm{~h}$ in $\mathrm{F}_{36} \mathrm{O}_{96}$ (Group 4) protocol were higher than in the other groups $(\mathrm{p}<0.05)$. In fact, the circulating levels of $\mathrm{E} 2$ from 36 to $76 \mathrm{~h}$ in $\mathrm{F}_{24} \mathrm{O}_{72}$ (Group 1) or 24 to $96 \mathrm{~h}$ in $\mathrm{F}_{24} \mathrm{O}_{96}$ (Group 2) protocol were maintained at a lower level than in the any of the other groups $(\mathrm{p}<0.05)$. Meanwhile, the circulating $\mathrm{P} 4$ concentrations were maintained at $<0.5$ $\mathrm{ng} / \mathrm{ml}$ in all treatment protocol groups throughout the experimental period (Figure 3B).

\section{In vitro embryo production}

The results of in vitro embryo production are presented in Table 3. The cleavage rates and day 8 blastocysts rate/oocytes or zygotes in the $\mathrm{F}_{36} \mathrm{O}_{72}$ (Group 3) protocol were higher than the other three groups $(\mathrm{p}<0.05)$, while COCs in $\mathrm{F}_{24} \mathrm{O}_{96}$ (Group 2) protocol showed lower efficiency for in vitro embryo production in terms of cleavage rates and day 8 blastocysts rates than in the other groups $\left(\mathrm{p}<0.05\right.$ ). In addition, COCs in the $\mathrm{F}_{24} \mathrm{O}_{72}$ (Group 1) protocol showed higher efficiency for in vitro embryo production in terms of cleavage rates expressed as day 8 blastocysts rates/oocytes or zygote than either $\mathrm{F}_{24} \mathrm{O}_{96}$ (Group 2) or $\mathrm{F}_{36} \mathrm{O}_{96}$ (Group 4) protocols $(\mathrm{p}<0.05)$.

\section{DISCUSSION}

There was poor documentation of ovarian follicular dynamics, oocyte yields and in vitro embryo production in Thai native heifers undergoing superstimulation of ovarian follicular growth and repeated OPU. In this study, sequential monitoring of follicular dynamics after superstimulation of ovarian follicular growth and repeated OPU sessions enabled characterization of follicular wave emergence, follicular deviation and its detrimental effects on quality of recovered $\mathrm{COCs}$ and subsequent in vitro embryo production in Thai native heifers. An important 

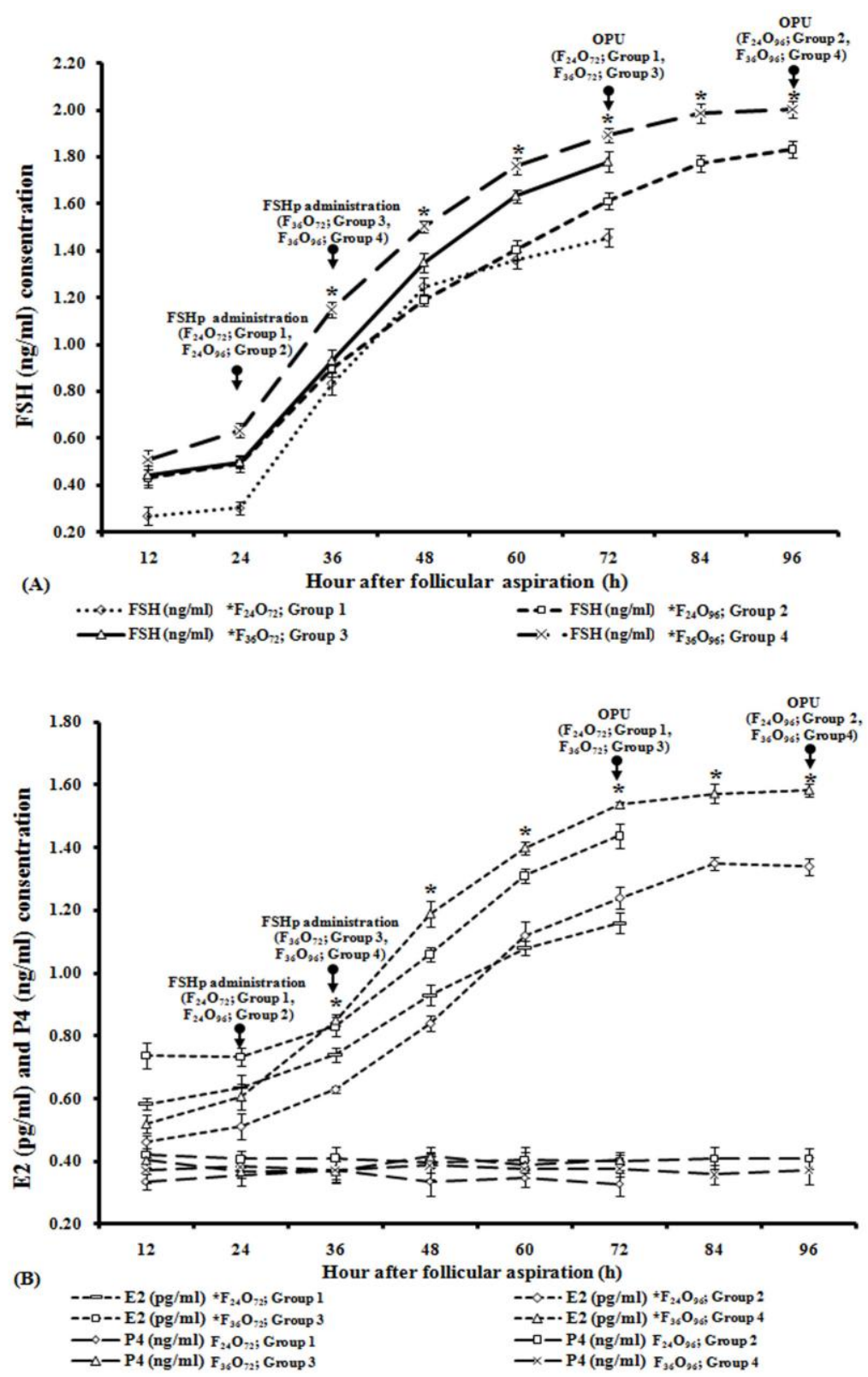

Figure 3. Plasma FSH (Figure 3A), Oestradiol-17ß (E2) and Progesterone (P4) (Figure 3B) concentrations after follicular aspiration undergoing repeated superstimulation of ovarian follicular growth and OPU in Thai native heifer. * Protocol code (Group), a single dose i.m. administration of $100 \mathrm{mg}$ FSHp at $24 \mathrm{~h}$ and OPU at $72\left(\mathrm{~F}_{24} \mathrm{O}_{72}\right.$; Group 1) or $96 \mathrm{~h}\left(\mathrm{~F}_{24} \mathrm{O}_{96}\right.$; Group 2), and a single dose i.m. administration of $100 \mathrm{mg}$ FSHp at $36 \mathrm{~h}$ and OPU at $72\left(\mathrm{~F}_{36} \mathrm{O}_{72}\right.$; Group 3) or $96 \mathrm{~h}\left(\mathrm{~F}_{36} \mathrm{O}_{96}\right.$; Group 4) after follicular ablation. Each dot represents mean \pm SEM. Values with asterisk $\left(^{*}\right)$ indicate significant differences in FSH concentration (Figure 3A) or E2 (Figure 3B) at the time of observation during OPU sessions after follicular aspiration among groups $(\mathrm{p}<0.05)$.

Table 3. In vitro fertilization and embryo development (Mean \pm SEM) on repeated superstimulation of ovarian follicular growth and OPU in Thai native heifers

\begin{tabular}{|c|c|c|c|c|c|c|c|c|c|}
\hline \multirow{2}{*}{$\begin{array}{l}\text { Protocol code* } \\
\text { (Group) }\end{array}$} & \multirow{2}{*}{$\begin{array}{c}\text { No. Oocytes culture } \\
\text { (categories A, B and C) }\end{array}$} & \multicolumn{2}{|c|}{ Cleaved zygote (n) } & \multirow{2}{*}{$\begin{array}{c}\text { Cleavage rate } \\
(\%)\end{array}$} & \multirow{2}{*}{$\begin{array}{c}\text { Cleaved } \\
\text { /heifer/session (n) }\end{array}$} & \multirow{2}{*}{$\begin{array}{c}\text { Day } 8 \\
\text { blastocysts (n) }\end{array}$} & \multicolumn{2}{|c|}{ Day 8 blastocysts rate } & \multirow{2}{*}{$\begin{array}{l}\text { Blastocysts/hei } \\
\text { fer/session (n) }\end{array}$} \\
\hline & & 2-cell & $\geq 4$ & & & & /Oocytes (\%) & /Zygote (\%) & \\
\hline$\overline{\mathrm{F}_{24} \mathrm{O}_{72} \text { (Group 1) }}$ & 438.00 & 237.00 & 141.00 & $86.30^{\mathrm{b}}$ & $9.45 \pm 1.24^{\mathrm{b}}$ & 140.0 & $31.96 \pm 1.03^{\mathrm{b}}$ & $37.03 \pm 1.06^{\mathrm{b}}$ & $3.50 \pm 0.39^{\mathrm{b}}$ \\
\hline $\mathrm{F}_{24} \mathrm{O}_{96}$ (Group 2) & 265.00 & 136.00 & 80.00 & $81.50^{\mathrm{d}}$ & $5.40 \pm 1.32^{\mathrm{c}}$ & 65.0 & $24.53 \pm 1.78^{\mathrm{d}}$ & $30.09 \pm 2.32^{\mathrm{d}}$ & $1.63 \pm 0.45^{\mathrm{c}}$ \\
\hline $\mathrm{F}_{36} \mathrm{O}_{72}$ (Group 3) & 719.00 & 440.00 & 234.00 & $93.74^{\mathrm{a}}$ & $16.58 \pm 1.23^{\mathrm{a}}$ & 272.0 & $37.83 \pm 2.45^{\mathrm{a}}$ & $40.39 \pm 1.58^{\mathrm{a}}$ & $6.80 \pm 0.79^{\mathrm{a}}$ \\
\hline $\mathrm{F}_{36} \mathrm{O}_{96}$ (Group 4) & 435.00 & 253.00 & 115.00 & $84.60^{c}$ & $9.20 \pm 1.17^{\mathrm{b}}$ & 126.0 & $28.96 \pm 1.48^{\mathrm{c}}$ & $34.24 \pm 1.02^{\mathrm{c}}$ & $3.15 \pm 0.37^{\mathrm{b}}$ \\
\hline
\end{tabular}

${ }_{\mathrm{a}, \mathrm{b}, \mathrm{c}, \mathrm{d}}$ Values followed by different superscripts within rows differ $(\mathrm{p}<0.05)$.

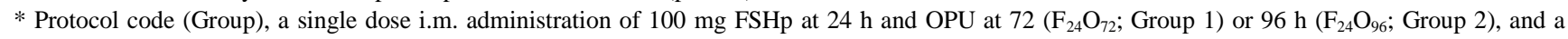
single dose i.m. administration of $100 \mathrm{mg} \mathrm{FSHp}$ at $36 \mathrm{~h}$ and OPU at $72\left(\mathrm{~F}_{36} \mathrm{O}_{72}\right.$; Group 3) or $96 \mathrm{~h}\left(\mathrm{~F}_{36} \mathrm{O}_{96}\right.$; Group 4) after follicular ablation. 
finding from this study was showed the follicular development in terms of numbers and size of follicles was influenced by the different times of a single dose FSHp administration after follicular ablation. Furthermore, the exogenous FSHp treatment for inducing follicular development influenced follicular growth rate, follicular size and follicle numbers. Moreover, the different times at which oocytes were harvested between OPU intervals influenced COCs quality and embryo production. The results showed that the follicle numbers were positively correlated with collected and cultured COCs and Day 8 blastocysts. In addition, the largest follicles $(>7 \mathrm{~mm}$ in diameter) were negatively correlated with COC quality.

In the present study, the new follicular waves emerged within $24 \mathrm{~h}$ after ablation of all follicles $\geq 3 \mathrm{~mm}$ in diameter. In contrast, it has been report that the emergence of new follicular waves occurred within $48 \mathrm{~h}$ in Gyr breed cows (Vianaet al., 2012) and Holstein-Friesian heifers (Garcia and Salaheddine, 1998) after removal of all follicles $\geq 3 \mathrm{~mm}$ in diameter. This indicated that the new follicular wave emergence after follicle ablation in Thai native heifers was earlier than in those breeds. Furthermore, the investigation of FSH profiles in this study showed a steady increase of FSH and culminating in a surge at 24 to $36 \mathrm{~h}$ after follicular ablation. In previous studies it was reported that removal of a dominant follicle resulted in an increased FSH concentration within $5 \mathrm{~h}$ and an endogenous FSH surge about 1.5 d later (Ginther et al., 1999), initiating a new follicular wave within $2 \mathrm{~d}$ (Ginther et al., 2001). The reasons for these differences between Thai Native heifers and those other breeds is difficult to explain, but may be due to the differences in follicular development between breeds (Chaubal et al., 2006).

In the present study, deviation of follicular growth into F1, F2 and F3 occurred at $24 \mathrm{~h}$ after follicular ablation; at this time of follicular deviation the diameters of the dominant follicles (F1) were approximately $4.0 \pm 0.4 \mathrm{~mm}$ and corresponded with time of endogenous FSH surge after follicular aspiration. Moreover, the selection of the dominant follicle occurs when the largest follicle achieves $5.5 \pm 0.2 \mathrm{~mm}$ in diameter. This supported the idea that establishment of dominant follicles, was due to rapid follicular growth. Furthermore, the differences in size and number of large follicles $(>7 \mathrm{~mm}$ in diameter) also corresponded to the differences in E2 production between groups. Meanwhile, a previous study has reported that the diameter of dominant follicle at selection was $6.2 \pm 0.3 \mathrm{~mm}$ in Gry cows and $8.5 \pm 0.3 \mathrm{~mm}$ in Nellore and HolsteinFriesian heifers (Garcia and Salaheddine, 1998; Castilho et al., 2007). While, the deviation of follicular growth commenced at $48 \mathrm{~h}, 36$ to $48 \mathrm{~h}$ and 48 to $96 \mathrm{~h}$ in Gry cows (Viana et al., 2012), Nellore heifers (Castilho et al., 2007) and Holstein-Friesian heifers (Garcia and Salaheddine,
1998) after follicular aspiration. This finding indicated that the diameter of the dominant follicle at deviation was smaller and the time of beginning of follicular deviation and the time of FSH surges after follicular aspiration in Thai native heifers were shorter than those previously reported in other breeds.

In the present study, induced follicular growth by a single dose administration of FSHp at $36 \mathrm{~h}$ in $\mathrm{F}_{36} \mathrm{O}_{72}$ (Group 3) and $\mathrm{F}_{36} \mathrm{O}_{96}$ (Group 4) after follicular ablation resulted in a higher ovarian response than in the $\mathrm{F}_{24} \mathrm{O}_{72}$ (Group 1) and $\mathrm{F}_{24} \mathrm{O}_{96}$ (Group 2) protocols were FSHp treated at $24 \mathrm{~h}$ after follicular ablation in terms of numbers of large antral follicles at the end of a OPU session. At $36 \mathrm{~h}$ after follicular ablation, the small follicles $\geq 4$ to $5 \mathrm{~mm}$ in diameter were recruited supported by the FSH surge. On the other hand, at $24 \mathrm{~h}$ after follicular aspiration only oocytes $\leq 3 \mathrm{~mm}$ in diameter were found and circulation of FSH was maintained at nadir levels. FSH is known to stimulate development of follicles starting at a diameter of 4 to $5 \mathrm{~mm}$ and reestablishment of a pool of large antral follicles corresponding with an FSH surge (Webb et al., 1999). Ginther et al. (2002) reported that the beginning of depression of the FSH receptors (FSHr) expressed in small follicles $>4 \mathrm{~mm}$ in diameter when they grow into larger diameter size promotes estradiol synthesis by the follicles. In fact, in the current study, the circulation levels of FSH and $\mathrm{E} 2$ from 36 to $72 \mathrm{~h}$ after follicular aspiration in $\mathrm{F}_{36} \mathrm{O}_{72}$ (Groups 3) and $\mathrm{F}_{36} \mathrm{O}_{96}$ protocols (Group 4) were higher than $\mathrm{F}_{24} \mathrm{O}_{72}$ (Group 1) and $\mathrm{F}_{24} \mathrm{O}_{96}$ (Group 2) protocol. FSH stimulation of granulosa cell proliferation is essential for the follicular and oocytes cell growth and development during the early antral stages (Ginther et al., 2002; Adriaens et al., 2004). Meanwhile, estrogen stimulated FSH receptor expression in primary and secondly bovine oocytes in granulosa cells (Hunzicker-Dunn and Maizels, 2006). It was directly linked to stimulation of folliculogenesis by synchronization of the follicular waves to increase the number of pre-antral follicles (Nakano et al., 1982). This may be the reason for a high ovarian response and a larger population of large antral follicles in $\mathrm{F}_{36} \mathrm{O}_{72}$ (Group 3) and $\mathrm{F}_{36} \mathrm{O}_{96}$ (Group 4) protocols. The number of follicles, leaving this growing pool and becoming FSH-sensitive depends, however, on other factors, such as insulin-like-growth factor (IGF), epidermal growth factor (EGF) (Nakano et al., 1982; Gutierrez et al., 2000) and the size of the growing pool (Cushman et al., 1999).

In the present study, the smaller diameter of the dominant follicle at deviation was consistent with the smaller final diameter of the dominant follicles in Thai native heifers. Furthermore, the establishment of dominant follicles during 72 or $96 \mathrm{~h}$ inter-OPU intervals may be due to the apparent faster growth rate of F1 than F2 and F3 as reported for Nellore (Sartorelli et al., 2005; Gimenes et al., 
2008) and Gyr cows (Viana et al., 2004; Viana et al., 2010). However, the initial diameters of F1, F2 and F3 among intervals between OPU sessions in all groups were similar. The large follicles in $\mathrm{F}_{24} \mathrm{O}_{96}$ (Groups 2) and $\mathrm{F}_{36} \mathrm{O}_{96}$ (Group 4) of OPU at $96 \mathrm{~h}$ following follicular ablation were due to the longer time for growing than the other two groups. Therefore, these groups showed higher maximum diameter and a larger population of large follicles $(>7 \mathrm{~mm}$ in diameter) at the end of OPU session than in the other groups. Furthermore, there was an effect of growth rate of F1 follicles on F2 and F3 growth; faster the growth of F1, the lower the growth rate of F2 and F3. This indicated that the F1 suppressed growth rate of F2 and F3 (Ginther et al., 2001).

In the present study, the percentage of COCs Grade A, B and $\mathrm{C}$ in the protocols in which OPU was performed at $72 \mathrm{~h}$ after follicular aspiration $\left(\mathrm{F}_{24} \mathrm{O}_{72}\right.$; Group 1 and $\mathrm{F}_{36} \mathrm{O}_{72}$; Group 3) was higher than in the protocols in which OPU was performed at $96 \mathrm{~h}\left(\mathrm{~F}_{24} \mathrm{O}_{96}\right.$; Group 2 and $\mathrm{F}_{36} \mathrm{O}_{96}$; Group 4). On the other hand, the percentage of COCs graded D and $\mathrm{E}$ was higher in the groups in which oocytes were harvested at $96 \mathrm{~h}$ than in the protocols in which OPU was performed at $72 \mathrm{~h}$ after follicular ablation. This implies that the interval between OPU sessions have an effect on COCs quality. The reason for this difference may be due to the 96 $\mathrm{h}$ interval between consecutive OPU sessions that allows the development of a dominant follicle which probably exerts a deleterious influence on oocytes development (Lucy, 2007). These oocytes are reported to be of lower quality and have already undergone cumulus expansion and atresia (Bergfelt et al., 1994; Bols et al., 1998). This may be the reason for the lower embryo development rate from the oocytes retrieved at $96 \mathrm{~h}$ after follicular aspiration. Therefore, this can be attributed to the aspiration of a newly recruited pool of follicles $3 \mathrm{~d}$ following the previous aspiration, that prevented establishment of a dominant follicle and regression of subordinate follicles, resulting in a more homogeneous cohort of oocytes (Bergfelt et al., 1994; Bols et al., 1998).

In the present study, there was a slower embryo development rate from the oocytes retrieved at $96 \mathrm{~h}$ after follicular aspiration than those recovered at $72 \mathrm{~h}$. It is speculated that this may be due to the longer period of suppression of the growth of small and medium follicles by a predominant follicle or the largest follicle $(>7 \mathrm{~mm}$ in diameter) than in the other group. In contrast, in the large follicles the follicular environment may permit greater storage of maternal mRNA and proteins within the oocyte, enhancing its capability of developing to the blastocyst stage. Furthermore, the higher developmental potential of oocytes originating from larger follicles has been attributed to the growth factors present in larger follicles (Lonergan et al., 1994), increased nuclear maturation (Fuhrer et al., 1989) and better cytoplasmic maturation (Ectors et al., 1995). In fact, in the present study, the largest follicle $(>7 \mathrm{~mm}$ in diameter) in the protocol of oocytes harvested at $96 \mathrm{~h}$ $\left(\mathrm{F}_{24} \mathrm{O}_{96}\right.$; Group 2 and $\mathrm{F}_{36} \mathrm{O}_{96}$; Group 4) was larger than the protocols of oocytes harvested at $72 \mathrm{~h}\left(\mathrm{~F}_{24} \mathrm{O}_{72}\right.$; Group 1 and $\mathrm{F}_{36} \mathrm{O}_{72}$; Group 3) after follicular aspiration. An embryo development rate in these protocols was slower than the protocols in which OPU was performed at $96 \mathrm{~h}$ after follicular ablation. This study does not separate follicle size into categories (large, medium, and small) for the investigation of embryo development from different follicle size in in vitro. Therefore, the influence of follicle size on embryo development in this case is difficult to explain. This may be because follicle size alone cannot be the only major influence on developmental competence (Sirard and Blondin, 1996).

In the present study, heifers in the protocols in which OPU was performed at $96 \mathrm{~h}$ after follicular aspiration (Group 2 and 4) showed higher circulatory levels of FSH and E2 concentrations at the end of OPU sessions in comparison with the groups in which OPU is carried out at $72 \mathrm{~h}$ post-follicular ablation irrespective of the mode of FSH treatment $\left(\mathrm{F}_{24} \mathrm{O}_{72}\right.$; Group 1 vs $\mathrm{F}_{24} \mathrm{O}_{96}$; Group 2, $\mathrm{F}_{36} \mathrm{O}_{72}$; Group 3 vs $\mathrm{F}_{36} \mathrm{O}_{96}$; Group 4). Furthermore, it was correlated with higher number of large follicle (>7 mm in diameter) in these groups. The quality of oocytes retrieved from $\mathrm{F}_{24} \mathrm{O}_{96}$ (Group 2) and $\mathrm{F}_{36} \mathrm{O}_{96}$ (Group 4) protocols, however, was lower than in $\mathrm{F}_{24} \mathrm{O}_{72}$ (Group 1) and $\mathrm{F}_{36} \mathrm{O}_{72}$ (Group 3) protocols in term of embryo development. The reason for this difference may be attributed to the higher number of pre-ovulatory follicles at the end of OPU sessions in these groups than the other two groups. In cattle the pre-ovulatory follicle contain high amounts of FSH, estrogen and IGF resulting in an increased concentration in follicular fluid for maintenance of healthy oocytes and their survival (Kastelic et al., 1990; Turzillo et al., 1993). Conversely, the concentrations of these hormones were decreased and lower concentrations were found in the subordinate follicles than in pre-ovulatory or the largest follicle at the time of deviation and selection (Kastelic et al., 1990; Turzillo et al., 1993; Mihm et al., 2000). In fact, FSH, estradiol and IGF are known as survival factors of ovarian follicles (Monniaux and Pisselet, 1992; Turzillo et al., 1993; Mihm et al., 2000), and therefore the decrease in these hormones in subdominant follicles (small and medium follicle) leads to disruption of receptor expression of these hormones in granulosa cells. This event signals induction of the Apoptosis-Inducing Factor (AIF) such as Bcl-2 family protein expressions (Tilly et al., 1995; Dhanabal et al., 1999). The Bcl-2 family includes Bax, Bab that are proapoptotic proteins and $\mathrm{Bcl}-2$; Bcl-x-long is an anti-apoptotic protein (Tilly et al., 1995; Dhanabal et al., 1999). It have been reported that the Bax was very high and Bcl-2 was at 
very low levels in small and medium follicles but it was just the opposite in largest or pre-ovulatory follicle at the time of selection and deviation (Chao and Korsmeyer, 1998). Therefore, the small and medium follicles were may be undergoing degeneration or atresia. This is consistent with the results of the present study because the groups of heifers OPU at $96 \mathrm{~h}$ after follicular aspiration showed a larger number of degenerate oocytes than other Groups at the end of OPU sessions.

In conclusion, a single dose administration of FSHp at $36 \mathrm{~h}$ and oocytes harvested at $72 \mathrm{~h}$ after follicular aspiration $\left(\mathrm{F}_{36} \mathrm{O}_{72}\right.$ protocol; Group 3) was the best protocol for superstimulation of ovarian follicular growth and repeated OPU and subsequent in vitro embryo production in Thai native heifers. Heifers were successfully stimulated repeatedly and oocytes harvested in eight OPU sessions, using a single dose i.m. administration of $100 \mathrm{mg}$ FSHp. This protocol gave a higher ovarian response, produced good quality COCs and higher embryo production in vitro. Future studies could explore the integration of OPU, in vitro embryo production and embryo transfer on a large-scale for increasing population numbers and integration of these technologies into animal breeding programs using Thai native cattle (B. indicus) donors.

\section{ACKNOWLEDGEMENTS}

The authors thank the Commission on Higher Education, Ministry of Education, Thailand for providing the scholarship under the Ministry Staff Development Project. We would also like to thank the Education Research Promotion and National Research University Project of Thai, Offices of the Higher Education Commission, through the Food and Function Food Research Cluster of Khon Kaen University for partial financial support. As well as, a part of this research was supported by WCU (World Class University) program (R31-10056) through the National Research Foundation of Korea funded by the Ministry of Education, Science and Technology.

\section{REFERENCES}

Adriaens, I., R. Cortvrindt and J. Smitz. 2004. Differential FSH exposure in preantral follicle culture has marked effects on folliculogenesis and oocyte developmental competence. Hum. Reprod. 19:398-408.

Allen, R. T., M. W. Cluck and D. K. Agrawal. 1998. Mechanisms controlling cellular suicide: role of $\mathrm{Bcl}-2$ and caspases. Cell. Mol. Life. Sci. 54:427-445.

Bergfelt, D. R., K. C. Lightfoot and G. P. Adams. 1994. Ovarian synchronization following ultrasound-guided transvaginal follicle ablation in heifers. Theriogenology 42:895-907.

Bols, P. E., M. T. Ysebaert, A. Lein, M. Coryn, A. Van Soom and A. de Kruif. 1998. Effects of long-term treatment with bovine somatotropin on follicular dynamics and subsequent oocyte and blastocyst yield in an OPU-IVF program. Theriogenology 49:983-995.

Bols, P. E., M. T. Ysebaert, A. Van Soom and A. De Kruif. 1997. Effects of needle tip bevel and aspiration procedure on the morphology and developmental capacity of bovine compact cumulus oocyte complexes. Theriogenology 47:1221-1236.

Castilho, C., J. M. Garcia, A. Renesto, G. P. Nogueira and L. F. Broto. 2007. Follicular dynamic and plasma FSH and progesterone concentration during follicular deviation in the first post ovulatory wave in Nellore heifer. Anim. Reprod. Sci. 98:189-196.

Chao, D. T. and S. J. Korsmeyer. 1998. Bcl-2 family: regulators of cell death. Annu. Rev. Immunol. 16:395-419.

Chasombat, J. and T. Vongpralub. 2011. Superstimulation of follicular growth in Thai native heifer by single administration of FSH dissolves in polyvinylpyrrolidone (PVP). Conference paper: SAADC 2011 strategies and challenges for sustainable animal agriculture-crop systems, Volume III: full papers. Proceedings of the 3rd International Conference on sustainable animal agriculture for developing countries, Nakhon Ratchasima, Thailand, 26-29 July, 2011; pp. 643-648.

Chaubal, S. A., J. A. Molina, C. L. Ohlrichs, L. B. Ferre, D. C. Faber, P. E. Bols, J. W. Riesen, X. Tian and X. Yang. 2006. Comparison of different transvaginal ovum pick-up protocols to optimise oocyte retrieval and embryo production over a 10week period in cows. Theriogenology 65:1631-1648.

Chaubal, S. A., L. B. Ferre, J. A. Molina, D. C. Faber, P. E. Bols, P. Rezamand, X. Tian and X. Yang. 2007. Hormonal treatments for increasing the oocyte and embryo production in an OPUIVP system. Theriogenology 67:719-728.

Crowe, M. A., V. Padmanabhan, N. Hynes, S. J. Sunderland, I. Z. Beitins and W. J. Enright. 1995. Validation of a sensitive RIA for measurement of serum FSH in cattle, and its correlation with FSH bioassay. J. Reprod. Fertil. 15:40 (Abstr).

Cushman, R. A., J. C. DeSouza, V. S. Hedgpeth and J. H. Britt. 1999. Superovulatory response of one ovary is related to the micro- and macroscopic population of follicles in the contralateral ovary of the cow. Biol. Reprod. 60:349-354.

De Roovera, R., G. Genicot, S. Leonard, P. Bols and F. Dessy. 2005. Ovum pick up and in vitro embryo production in cows superstimulated with an individually adapted superstimulation protocol. Anim. Reprod. Sci. 86:13-25.

Department of Livestock Development (DLD) of Thailand. 2011. Number of livestock and farmer, Annual report. pp. 1-4.

Dhanabal, M., R. Ramchandran, M. J. Waterman, H. Lu, B. Knebelmann, M. Segal and V. P. Sukhatme. 1999. Endostatin induces endothelial cell apoptosis. J. Biol. Chem. 274:1172111726.

Ectors, F. J., L. Koulischer, M. Jamar, C. Herens, A. Verloes and B. Remy. 1995. Cytogenetic study of bovine oocytes matured in vitro. Theriogenology 44:445-450.

FAO. 2006. Livestock impacts on the environment. Food and Agriculture Organization of the United Nations, Rome, Italy.

Fuhrer, F., B. Mayer, K. Schellander, M. Kalat and W. Schleger. 1989. Maturation competence and chromatin behavior in growing and fully grown cattle oocytes. Zentralbl. Veterinarmed. A. 36:285-291.

Galli, C., G. Crotti, C. Notari, P. Turini, R. Duchi and G. Lazzari. 2001. Embryo production by ovum pick up from live donors. 
Theriogenology 55:1341-1357.

Galli, C., R. Duchi, G. Crotti, P. Turini, N. Ponderato, S. Colleoni, I. Langutina and G. Lazzari. 2003. Bovine embryo technologies. Theriogenology 59:599-616.

Garcia, A. and M. Salaheddine. 1998. Effects of repeated ultrasound-guided transvaginal follicular aspiration on bovine oocyte recovery and subsequent follicular development. Theriogenology 50:575-585.

Gimenes, L. U., M. F. Sa' Filho, N. A. Carvalho, J. R. TorresJu'nior, A. H. Souza, E. H. Madureira, L. A. Trinca, E. S. Sartorelli, C. M. Barros, J. B. Carvalho, R. J. Mapletoft and P. S. Baruselli. 2008. Follicle deviation and ovulatory capacity in Bos indicus heifers. Theriogenology 69:852-858.

Ginther, O. J., D. R. Bergfelt, L. J. Kulick and K. Kot. 1999. Selection of the dominant follicle in cattle: establishment of follicle deviation in less than $8 \mathrm{~h}$ through depression of FSH concentrations. Theriogenology 52:1079-1093.

Ginther, O. J., D. R. Bergfelt, M. A. Beg and K. Kot. 2001. Follicle selection in cattle: relationships among growth rate, diameter ranging, and capacity for dominance. Biol. Reprod. 65:345-350.

Ginther, O. J., D. R. Bergfelt, M. A. Beg and K. Kot. 2002. Role of low circulating FSH concentrations in controlling the interval to emergence of the subsequent follicular wave in cattle. Reproduction 124:475-482.

Gutierrez, C. G., J. H. Ralph, E. E. Telfer, I. Wilmut and R. Webb. 2000. Growth and antrum formation of bovine preantral follicles in long-term culture in vitro. Biol. Reprod. 62:13221328.

Holm, P., P. J. Booth, M. H. Schmidt, T. Greve and H. Callesen. 1999. High bovine blastocyst development in a static in vitro production system using SOFaa medium supplemented with sodium citrate and myo-inositol with or without serum proteins. Theriogenology 52:683-700.

Hunzicker-Dunn, M. and E. T. Maizels. 2006. FSH signaling pathways in immature granulosa cells that regulate target gene expression: branching out fromprotein kinase A. Cell Signal. 18:1351-1359.

Kabubo-Mariara, J. 2009. Global warming and livestock husbandry in Kenya: Impacts and adaptations. Ecol. Econ. 68:1915-1924.

Kastelic, J. P., J. C. Ko and O. J. Ginther. 1990. Suppression of dominant and subordinate ovarian follicles by a proteinaceous fraction of follicular fluid in heifers. Theriogenology 34:499559.

Kohram, H., H. Twagiramungu, D. Bousquet, J. Durocher and L. A. Guilbault. 1998. Ovarian superstimulation after follicular wave synchronization with GnRH at two difference stages of the estrus cycle in cattle. Theriogenology 49:1175-1186.

Koneswaran, G. and D. Nierenberg. 2008. Global farm animal production and global warming: Impacting and mitigating climate change. Environ. Health Perspect. 116:578-582.

Lindner, G. M. and Jr. R. W. Wright. 1983. Bovine embryo morphology and evaluation. Theriogenology 20:407-416.

Lonergan, P., P. Monaghan, D. Rizos, M. P. Boland and I. Gordon. 1994. Effect of follicle size on bovine oocyte quality and developmental competence following maturation, fertilization and culture in vitro. Mol. Reprod. Dev. 37:48-53.
Lowman, B. G., N. A. Scott and S. H. Smerville. 1976. Condition scoring of cattle. The East of Scotland College of Agriculture, Edinburgh, pp. 1-31 (Bulletin 6).

Lucy, M. C. 2007. The bovine dominant ovarian follicle. J. Anim. Sci. E85-E99 (Suppl.)

Mann, G. E., G. E. Lamming and M. D. Fray. 1995. Plasma oestradiol and progesterone during early pregnancy in the cow and the effects of treatment with buserelin. Anim. Reprod. Sci. 37:121-131.

McNeilly, A. S. and H. M. Fraser. 1987. Effect of gonadotrophinreleasing hormone agonist-induced suppression of $\mathrm{LH}$ and FSH on follicle growth and corpus luteum function in the ewe. J. Endocrinol. 115:273-282.

Mihm, M., E. J. Austin, T. E. Good, J. L. Ireland, P. G. Knight, J. F. Roche and J. J. Ireland. 2000. Identification of potential intrafollicular factors involved in selection of dominant follicles in heifers. Biol. Reprod. 63:811-819.

Monniaux, D. and C. Pisselet. 1992. Control of proliferation and differentiation of ovine granulosa cells by insulin-like growth factor-I and follicle-stimulating hormone in vitro. Biol. Reprod. 46:109-119.

Monteiro, F. M., M. M. Ferreira, J. R. Potiens, B. G. Eberhardt, L. A. Trinca and C. M. Barros. 2010. Influence of superovulatory protocols on in vitro production of Nellore (Bos indicus) Embryos. Reprod. Domest. Anim. 45:860-864.

Nakano, R., T. Nakayama and M. Iwao. 1982. Inhibition of ovarian follicle growth by a chemical antiestrogen. Horm. Res. 16:230-236.

Parrish, J. J., A. Krogenaes and J. L. Susko-Parrish. 1995. Effect of bovine sperm separation by either swim-up and percoll method on success of in vitro fertilization and early embryonic development. Theriogenology 44:859-869.

Pieterse, M. C., P. L. A. M. Vos, Th. A. M. Kruip, Y. A. Wurth, Th. H. van Beneden, A. H. Willemse and M. A. M. Taverne. 1992. Repeated transvaginal ultrasound-guided ovum pick-up in PMSG-treated cows. Theriogenology 37:273 (Abstr.).

Ratto, M. H., O. A. Peralta, G. Mogollon, P. Strobel and J. Correa. 2011. Transvaginal ultrasound-guided cumulus oocyte complexes aspiration and in vitro embryo production in suckled beef and lactating dairy cattle on pasture-based management conditions. Anim. Reprod. Sci. 129:1-6.

Reis, A., M. E. Staines, R. G. Watt, D. F. Dolman and T. G. McEvoy. 2001. Embryo production using defined oocyte maturation and zygote culture media following repeated ovum pick-up (OPU) from FSH-stimulated Simmental heifers. Anim. Reprod. Sci. 72:137-151.

Richards, J. S., S. L. Fitzpatrick, J. W. Clemens, J. K. Morris, T. Alliston and J. Sirois. 1995. Ovarian cell differentiation: a cascade of multiple hormones, cellular signals, and regulated genes. Recent Prog. Horm. Res. 50:223-254.

Sakhong, D., T. Vongpralub, S. Katawatin and S. Sirisathien. 2011. Ovarian follicular patterns and hormone profile in thai native cattle (Bos indicus). Thai J. Vet. Med. 41:439-447.

Sartorelli, E. S., L. M. Carvalho, D. R. Bergfelt, O. J. Ginther and C. M. Barros. 2005. Morphological characterization of follicle deviation in Nelore (Bos indicus) heifers and cows. Theriogenology 63:2382-2394.

Sartori, R., P. M. Fricke, J. C. Ferreira, O. J. Ginther and M. C. Wiltbank. 2001. Follicular deviation and acquisition of 
ovulatory capacity in bovine follicles. Biol. Reprod. 65:14031409.

SAS. 1998. SAS User's Guide for Personal Computers. SAS Institute, Inc., Cary, NC, USA.

Sendag, S., Y. Cetin, M. Alan, K. G. Hadeler and H. Niemann. 2008. Effects of eCG and FSH on ovarian response, recovery rate and number and quality of oocytes obtained by ovum pick-up in Holstein cows. Anim. Reprod. Sci. 106:208-214.

Sirard, M. A. and P. Blondin. 1996. Oocyte maturation and IVF in cattle. Anim. Reprod. Sci. 42:417-426.

Tilly, J. L., K. I. Tilly, M. L. Kenton and A. L. Johnson. 1995. Expression of members of the Bcl-2 gene family in the immature rat ovary: equine chorionic gonadotropin-mediated inhibition of granulosa cell apoptosis is associated with decreased Bax and constitutive Bcl-2 and Bcl-X long messenger ribonucleic acid levels. Endocrinology 136:232-241.

TMD. 2005. Thai meteorological Department report. J. Thai Meteorology. Available online: http://www.tmd.go.th.
Tomley, F. M. and M. W. Shirley. 2009. Livestock infectious diseases and zoonoses. Philos. Trans. R. Soc. Lond. B. Biol. Sci. 64:2637-2642.

Turzillo, A. M. and J. E. Fortune. 1993. Effect of surppressing plasma FSH on ovarian follicular dominance in cattle. J. Reprod. Fertil. 98:113-119

Viana, J. H., L. S. Camargo, A. M. Ferreira, W. F. Sa', C. A. Fernandes and A. P. Marques Ju'nior. 2004. Short intervals between ultrasonographically-guided follicle aspiration improve oocyte quality but do not prevent establishment of dominant follicles in the Gir breed (Bos indicus) of cattle. Anim. Reprod. Sci. 84:1-12.

Viana, J. H., M. P. Palhao, L. G. Siqueira, J. F. Fonseca and L. S. Camargo. 2010. Ovarian follicular dynamics, follicle deviation, and oocyte yield in Gyr breed (Bos indicus) cows undergoing repeated ovum pick-up. Theriogenology 73:966-972.

Webb, R., B. K. Campbell, H. A. Garverick, J. G. Gong, C. G. Gutierrez and D. G. Armstrong. 1999. Molecular mechanisms regulating follicular recruitment and selection. J. Reprod. Fertil. Suppl. 54:33-48. 